\title{
Preliminary investigation of the hydrocarbon generation potential from the post-rift Abbas shale Formation (Pliocene) in the Tihamah Basin, south-eastern Yemeni Red Sea
}

\author{
Mohammed Hail Hakimi ${ }^{1}$ Abbas F. Gharib ${ }^{2}$ - Nor Syazwani Z. Abidin ${ }^{3} \cdot$ Madyan M. A. Yahya $^{1,4}$
}

Received: 2 July 2020 / Accepted: 9 November 2020 / Published online: 22 November 2020

(c) The Author(s) 2020

\begin{abstract}
Pliocene shales included in the post-rift Abbas Formation were recovered from an exploratory well (Kathib-01) in the Tihamah Basin and geochemically analyzed. A preliminary evaluation of the organic facies of the Abbas shales and their petroleum generation potential was conducted based on basic organic geochemical results. Most Abbas shale samples had total organic carbon (TOC) contents $<1 \%$ and a fair source potential, while the remaining samples, with TOC contents $>1 \%$, had a relatively good potential. Overall, the Rock-Eval hydrogen index values of the shales analyzed were between 96 and $234 \mathrm{mg}$ of hydrocarbon per gram of TOC (mg HC/g TOC), indicating two dominant organic facies: types III and II/III kerogen, which indicate the presence of mainly gas- and oil-prone source rocks. We conclude that the Pliocene Abbas shales in the Tihamah Basin are still in a very early-mature stage (with respect to the oil window) and, hence, have not generated petroleum yet.
\end{abstract}

Keywords Pliocene shale $\cdot$ Abbas Formation · Petroleum generation potential · Tihamah Basin $\cdot$ Yemeni Red Sea

\section{Introduction}

The hydrocarbon exploration history of the Tihamah Basin, which is located in the south-eastern Yemeni Red Sea (Fig 1a), began many years ago. In 1960, around 12 exploration wells were drilled in the onshore and offshore portions of the Tihamah Basin, Yemen (Fig 1b). These wells are operated by multiple petroleum-operating companies, such as Mecom, Hunt, Total, and Shell. Moreover, the presence of oil seeps in the As-Salif peninsula, its onshore migration, and the presence of oil and gas in several onshore

Mohammed Hail Hakimi

ibnalhakimi@yahoo.com

1 Geology Department, Faculty of Applied Science, Taiz University, 6803 Taiz, Yemen

2 Oil and Gas Economics, Imam Jaafar AI-Sadiq University, Kirkuk, Iraq

3 Geosciences Department, Faculty of Science and Information Technology, Universiti Teknologi PETRONAS,

32610 Bandar Seri Iskandar, Perak, Malaysia

4 Department of Petroleum Geology and Sedimentation, Faculty of Earth Sciences, University of King Abdulaziz, Jeddah, Saudi Arabia and offshore wells in the Tihamah Basin (e.g., SPT 1994), suggested the presence of several proven source rocks and encouraged further petroleum geochemistry studies. Several geochemistry works have been conducted on shale rocks contained in the corresponding (syn- and post-rift) sedimentary successions. A recent study by Hakimi et al. (2016) indicated that the syn-rift Salif Formation contains organic-rich shales, which are considered the main source rocks in the Tihamah Basin. The Salif organic-rich shales are characterized by a relatively high total organic carbon (TOC) content ( $>3 \%$ ) and mainly type II and mixed II-III kerogens, with a minor contribution of type III kerogen, indicating that they are mainly oil-and gas-prone source rocks (Hakimi et al. 2016). The current study focused on the overlain shales of the post-rift Abbas Formation and compared the results with those of recent studies on the organic-rich interval of the syn-rift Salif Formation. In this way, we expected to obtain a big picture of the petroleum resources in the Shabwah subbasin, useful for future explorations. This study aimed to provide information on the source rock characteristics of the Abbas shale Formation, particularly with respect to their quantity, quality, level of thermal maturity, and potential for hydrocarbon generation. A total of 10 cutting shale samples were collected from an exploratory well located offshore in 


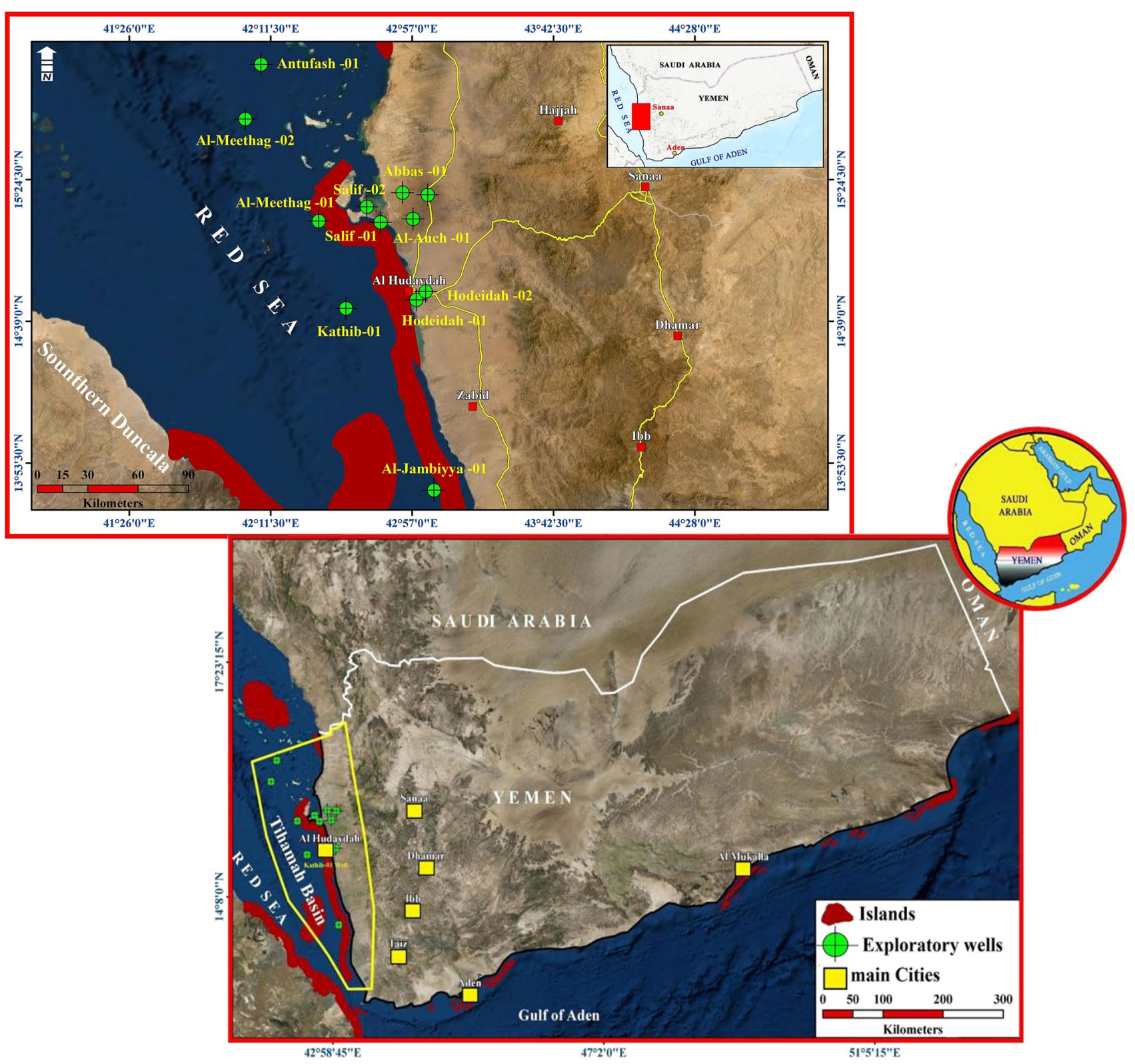

Fig. 1 a Main sedimentary basins in the Republic of Yemen (modified after Beydoun et al. 1998) and b location map of exploration wells in the Tihamah Basin (south-eastern Yemeni Red Sea), including the studied well (i.e., Kathib-01)

the Tihamah Basin (i.e., Kathib-01; see Fig 1b) and were subjected to basic organic geochemical analyses.

\section{Geological setting}

The Tihamah Basin extends in the south-eastern part of the Yemeni Red Sea (Fig 1a), from the onshore to offshore. This sea was initially formed owing to early Oligocene and Tertiary rifting and then by recent tectonic movements (Redfern and Jones 1995; As-Saruri et al. 2010). The Tihamah Basin is structurally part of a tectonic zone of the Red Sea rifting, which resulted from the detachment of the Arabian Peninsula from the African Plate (Fig 2; Redfern and Jones 1995). The tectonic rifting is manifested by parallel normal faults and several related structural elements, such as horsts and tilted fault blocks (Tari et al. 2014; Bawazer et al. 2018). The Tihamah Basin is filled with a thick sedimentary succession, belonging to the Early Miocene-Pleistocene (Fig 3), and represented by the Tihamah Group (Beydoun et al. 1998; As-Saruri et al. 2010). The Tihamah sediments were related mainly to the tectono-stratigraphic (i.e., syn- and post-rift) conditions: They accumulated in marine, transitional, and continental depositional environments (As-Saruri et al. 


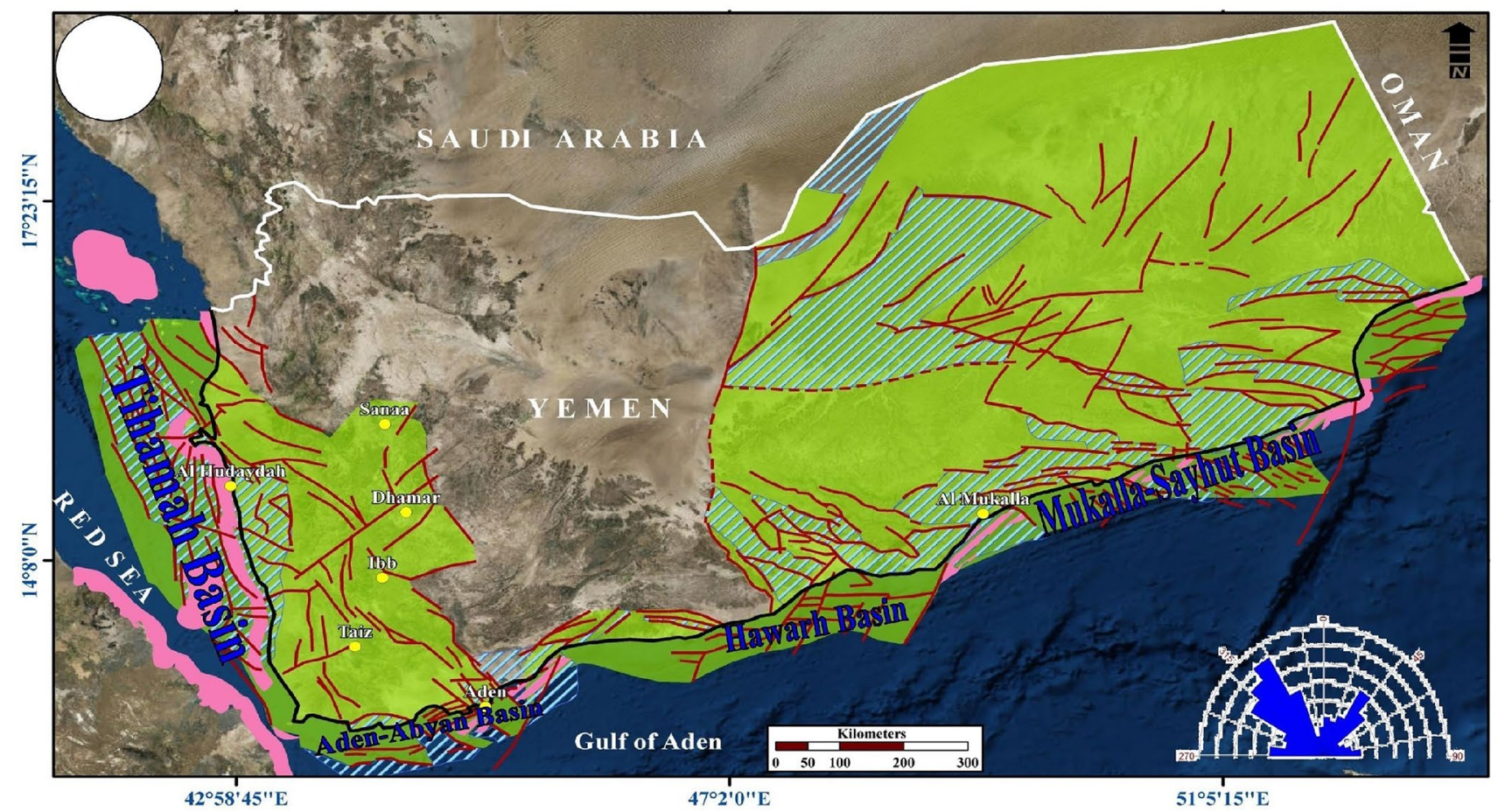

Fig. 2 Main offshore sedimentary basins in the Republic of Yemen, including the Tihamah Basin. The figure shows the formation of the offshore Aden-Abyan, Hawarh, Mukalla-Sayhut, and Tihamah Basins during the Oligocene-Miocene rifting (modified after SPT 1994)

2010). Prior to the first period of sedimentation, Tertiary volcanic rocks formed in the Tihamah Basin during the late Oligocene (Fig 3), and their formation accelerated during the late Pliocene (Mattash 1994; Al-Kadasi 1994; Nasher 2010). These Tertiary volcanic rocks are related to the evolution of the Red Sea and the Gulf of Aden (Mattash 1994; Al-Kadasi 1994; Redfern and Jones 1995; Nasher 2010).

The syn-rift sequences of the Zaydiyah, Maqna, and Salif formations were deposited during the early-late Miocene. Notably, they include mainly clastic sediments and evaporites and lie unconformably on volcanic rocks (Fig 3). The Zaydiyah Formation includes predominantly clastic sediments overlain conformably by marine sediments of the Maqna Formation (Fig 3). This latter formation mainly consists of shale with interbedded sandstones and is conformably overlain by the middle-late Miocene Salif Formation (Fig 3). The Salif Formation is composed of mixed marine evaporites with subordinate shales and sandstones (Fig 3). Among them, organic-rich shales were deposited in a marine anoxic environment under highly reducing conditions: They contain large amounts of algal and microbial organic matter and a lower amount of terrigenous organic matter (Hakimi et al. 2016).

The mixed clastic-carbonate sediments of the post-rift sequence conformably cover the Salif Formation (Fig 3).
The post-rift sequence is represented by Pliocene-Pleistocene Abbas clastics and Kamaran carbonates. The Abbas Formation is composed mainly of sandstone and mudstone; moreover, it presents vertical variations of thickness and lateral facies changes (from clastics to carbonate facies). These variations and changes were created along the shore of the Yemeni Red Sea during the deposition of organic reef limestone in the Pleistocene and are included in the Kamaran Member (Fig 3).

\section{Materials and methods}

The data used in this study include conventional organic geochemical results obtained from 10 cutting samples collected from an exploratory well (i.e., Kathib-01) in the Tihamah Basin, south-eastern Yemeni Red Sea (Fig 1b and Table 1). These samples were extracted from a shale unit within the post-rift Abbas Formation (Fig 3). Prior to the geochemical analytical process, the drilling mud and other drilling additives were removed using cold freshwater. The standard organic geochemical analyses included measurements of the TOC content and Rock-Eval pyrolysis analyses (conducted at specialized geochemical laboratories). 


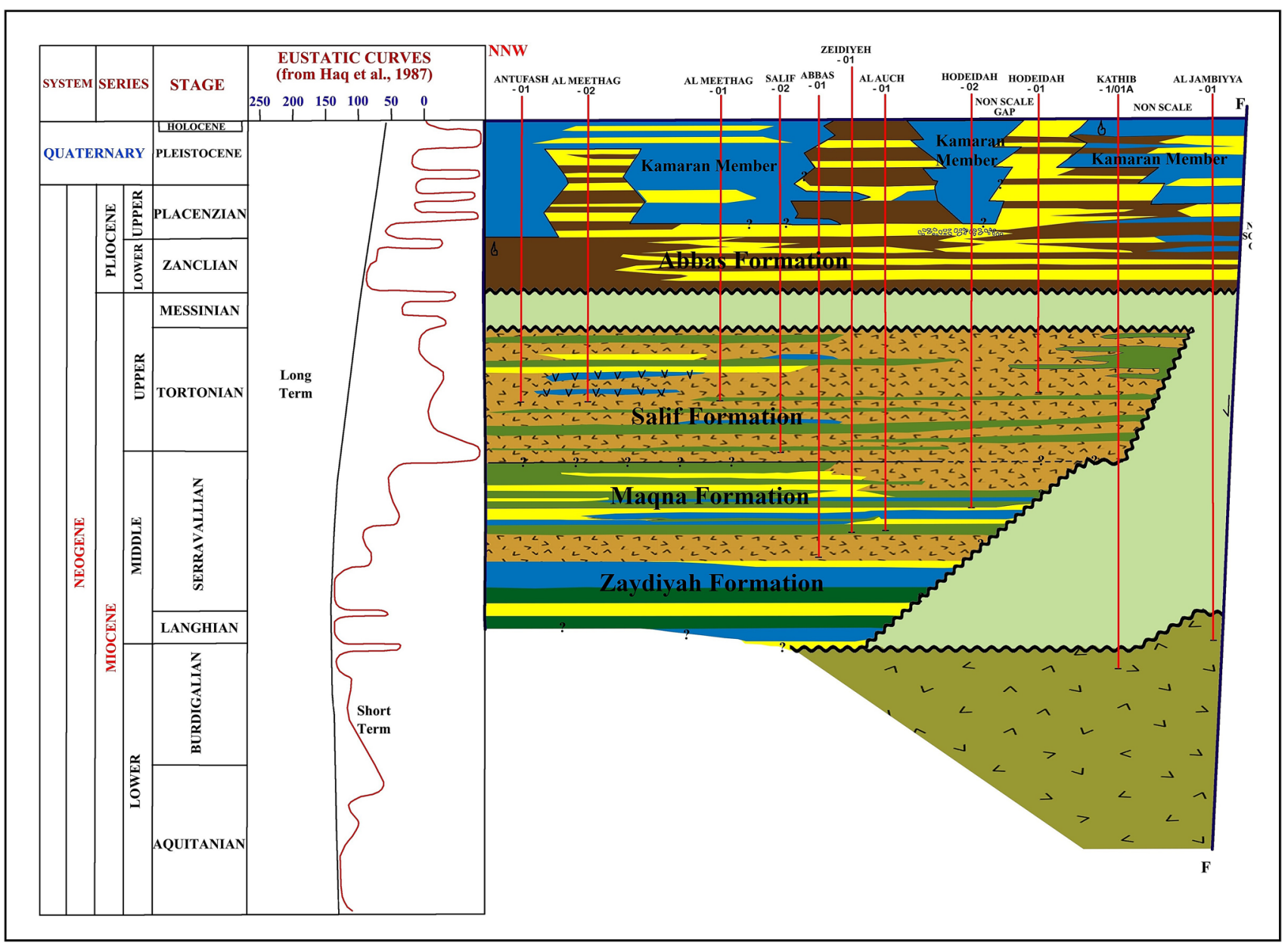

Fig. 3 Generalized stratigraphic column of the Miocene-Pliocene sequences in the Tihamah Basin (modified after SPT 1994)

Table 1 Basic geochemical results of the analyzed shale samples in the post-rift Abbas Formation (Pliocene) in the Tihamah Basin, south-eastern Yemeni Red Sea, including TOC content and measured and calculated Rock-Eval pyrolysis parameters

\begin{tabular}{|c|c|c|c|c|c|c|c|c|}
\hline \multirow[t]{3}{*}{ Wells } & \multirow[t]{3}{*}{ Depths (m) } & \multirow[t]{3}{*}{ TOC Wt.\% } & \multicolumn{6}{|c|}{ Rock-Eval pyrolysis data } \\
\hline & & & \multicolumn{3}{|c|}{ Measured parameters } & \multicolumn{3}{|c|}{ Calculated parameters } \\
\hline & & & $S_{1}(\mathrm{mg} / \mathrm{g})$ & $S_{2}(\mathrm{mg} / \mathrm{g})$ & $T_{\max }\left({ }^{\circ} \mathrm{C}\right)$ & $\mathrm{PY}(\mathrm{mg} / \mathrm{g})$ & PI (mg/g) & $\mathrm{HI}(\mathrm{mg} / \mathrm{g})$ \\
\hline \multirow[t]{10}{*}{ Kathib-01 Well } & 1070 & 0.50 & 0.04 & 0.89 & 430 & 0.93 & 0.04 & 178 \\
\hline & 1080 & 0.57 & 0.08 & 0.96 & 444 & 1.04 & 0.08 & 168 \\
\hline & 1110 & 0.88 & 0.10 & 1.73 & 429 & 1.83 & 0.06 & 197 \\
\hline & 1140 & 0.62 & 0.04 & 0.87 & 431 & 0.91 & 0.05 & 140 \\
\hline & 1190 & 0.56 & 0.05 & 0.54 & 435 & 0.59 & 0.08 & 96 \\
\hline & 1407 & 1.01 & 0.33 & 2.35 & 434 & 2.68 & 0.12 & 233 \\
\hline & 1419 & 1.03 & 0.34 & 2.41 & 433 & 2.75 & 0.12 & 234 \\
\hline & 1428 & 0.81 & 0.31 & 1.85 & 435 & 2.16 & 0.14 & 228 \\
\hline & 1440 & 0.59 & 0.24 & 0.95 & 434 & 1.19 & 0.20 & 161 \\
\hline & 1566 & 0.53 & 0.33 & 0.89 & 431 & 1.22 & 0.27 & 168 \\
\hline
\end{tabular}

TOC total organic carbon, wt $\%$; $S_{1}$ volatile hydrocarbon $(\mathrm{HC})$ content, $\mathrm{mg} \mathrm{HC/} \mathrm{g} \mathrm{rock;} S_{2}$ remaining HC generative potential, mg HC/g rock; $H I$ hydrogen index $=S_{2} \times 100 / \mathrm{TOC}, \mathrm{mg} \mathrm{HC} / \mathrm{g}$ TOC; $P Y$ potential yield $=S_{1}+S_{2}(\mathrm{mg} / \mathrm{g})$; MI: migration index $=\mathrm{S} 1 * 100 / \mathrm{TOC}$; PI: production index $=S_{1} /\left(S_{1}+S_{2}\right)$ 
The whole-rock samples were crushed to fine particles and subsequently analyzed to determine the TOC content using a LECO CS-125 equipment. Rock-Eval pyrolysis analyses were subsequently performed on the powdered samples using a Rock-Eval II instrument. The results of the latter analysis provided three important parameters: the total free petroleum ( $S_{1}$ peak, $\mathrm{mg} / \mathrm{g}$ ), the hydrocarbon yield from kerogen cracking $\left(S_{2}\right.$ peak, $\left.\mathrm{mg} / \mathrm{g}\right)$, and the highest temperature at which the maximum $S_{2}$ is generated during pyrolysis $\left(T_{\max }\right)$. Based on the TOC content and the Rock-Eval yields (i.e., $S_{1}$ and $S_{2}$ ), we could mathematically calculate additional geochemical parameters: the hydrogen index $\left(\mathrm{HI}=S_{2} \times 100 / \mathrm{TOC}\right)$, the petroleum yield $\left(\mathrm{PY}=S_{1}+S_{2}\right)$, and the production index $\left(\mathrm{PI}=S_{1} / S_{1}+S_{2}\right)$ (Table 1$)$.

\section{Results and discussion}

\section{Total organic carbon (TOC) content and generative potential}

The TOC content of the source rocks and their generative potential can be used to identify the amount of organic matter and the petroleum generation potential on thermal maturity (Peters and Cassa 1994; Hunt 1996; Shah and Ahmed 2018). In this study, the generative potential of the shale samples analyzed was evaluated from the organic geochemical results: the TOC content and the yields of $S_{1}$ and $S_{2}$ (Peter and Casa 1994; Hunt 1996; Shah and Ahmed 2018). The TOC content is indicated commonly in terms of weight percent (Peter and Casa 1994; Hunt 1996); notably, the minimum TOC content value associated with shale source rocks is $\geq 0.5 \mathrm{wt} \%$ (Tissot and Welte 1984). Here, the source rocks with TOC content $<1 \mathrm{wt} \%$ and up to $1 \mathrm{wt} \%$ were classified as "fair potential" and "good-excellent" source rocks, respectively (Peters and Cassa 1994). Most of the Abbas shale samples analyzed showed TOC values between 0.50 and $1.03 \mathrm{wt} \%$ (Table 1) and were, hence, considered as fair source rocks (Fig 4a). Only two samples showed TOC values slightly $>1 \%$, indicating their higher potential (i.e., good potential) as source rocks (Fig 4a). However, knowing the TOC content alone is not sufficient to determine the generative potential of source rocks: It must be considered in parallel with the Rock-Eval $S_{2}$ yield (Peters 1986; Peters and Cassa 1994; Hunt 1996; Dembicki 2009). Based on the $S_{2}$ and TOC data, we can conclude that most of the samples analyzed had a fair-good generative potential (Fig 4b).

\section{Types of organic matter}

The types of kerogen contained in the Abbas shale Formation were evaluated considering the basic geochemical results. The Rock-Eval hydrogen (HI) and oxygen (OI) indices can be used to describe the bulk kerogen types present in source rocks (Peters and Cassa 1994; Hunt 1996). In this study, the Rock-Eval instrument did not measure the carbon oxide content (i.e., the $S_{3}$ peak); hence, no information on the oxygen content was obtained, and the kerogen type present in the samples analyzed was identified based on the HI. The potential of a source rock to generate hydrocarbons is usually determined from the HI rather than from the OI: The latter index is not accurate, because the oxygen released from the organic matter combines with that released from carbonates or the oxidation of kerogen (Tissot and Welte 1984; Espitalié et al. 1985; Mukhopadhyay et al. 1995). The HI pyrolysis parameter of the samples analyzed was in the range of 96-234 mg of hydrocarbon per gram of TOC ( $\mathrm{mg}$ $\mathrm{HC} / \mathrm{g}$ TOC) (Table 1). According to the modified van Krevelen diagram obtained by combining the Rock-Eval HI and $T_{\max }$ results, the organic matter in the samples analyzed was represented predominantly by types III and III/II kerogen (Fig 5a). These types of kerogen were further determined from a cross-plot of $S_{2}$ versus TOC (first proposed by Langford and Blanc-Valleron 1990). In fact, the HI values were calculated mathematically based on the TOC content and the Rock-Eval $S_{2}$ values: HI $=S_{2} \times 100 /$ TOC (Peters and Cassa 1994). The analysis of the cross-plot confirmed that the samples from the Kathib-01 well contained mainly types III and II/III kerogen (Fig 5b). These results are in good agreement with the interpretation based on the modified van Krevelen diagram.

\section{Thermal maturation of organic matter}

The degree of thermal alteration of the organic matter (due to heating) was defined as "maturation" (Peters and Cassa 1994). Geochemical data (i.e., $T_{\max }$ and PI values) can be used to estimate the maturation of organic matter in source rocks (Peters and Cassa 1994). The maximum temperature ( $T_{\max }$ ) of the $S_{2}$ peak was measured during the pyrolysis analysis: It varied between $429{ }^{\circ} \mathrm{C}$ and $444{ }^{\circ} \mathrm{C}$, indicating that the source rocks were in the early stage of maturity with respect to the oil-generation window (Peters and Cassa 1994). In the case of abnormally low $T_{\max }$ values, PI values are used as geochemical maturity indicators for source rocks (Peters and Cassa 1994). In this study, the samples analyzed had PI values between 0.04 and 0.27 (Table 1), further indicating a source rock in the early stage of maturity with respect to the oil-generation window (Fig 6). Furthermore, the $S_{1}$ yields (representing the free hydrocarbons, including gas and oil) were lower than the $S_{2}$ yields (Table 1), indicating that the organic matter had a low level of maturity and had not yet generated commercial petroleum. This low maturity level can be attributed to the 
Total organic matter carbon (TOC, wt. \%)
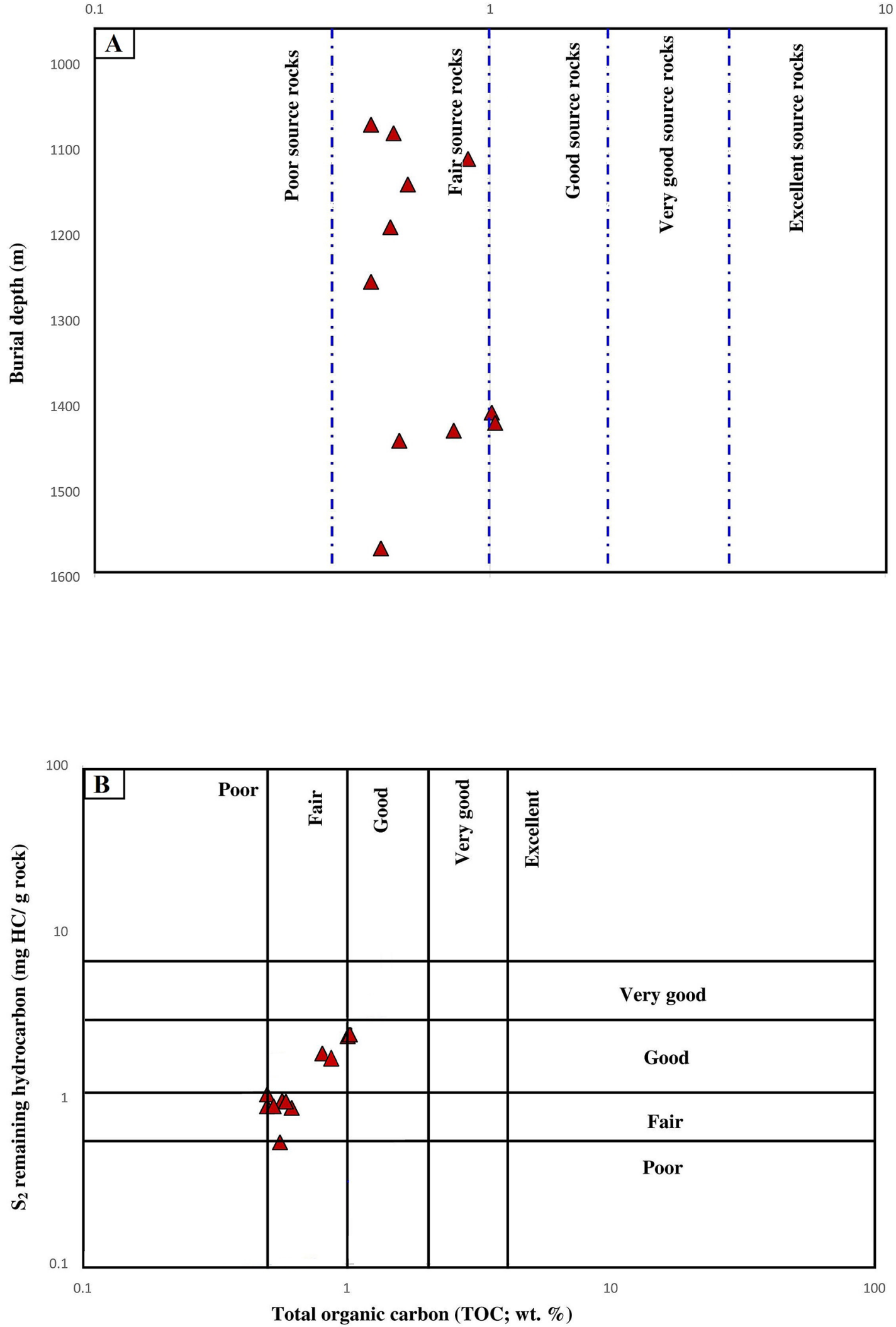
4Fig. 4 a Distribution of the TOC content within adjacent depths of the Abbas shales in the studied well; $\mathbf{b}$ geochemical correlation between the TOC content and the potential petroleum yield $\left(S_{1}+S_{2}\right)$, indicating the presence of favorable source rocks (fair-good petroleum generation potential)

shallow burial depth of the Abbas Formation $(<1600 \mathrm{~m})$ (Table 1).

\section{Hydrocarbon generation potential}

The kerogen facies dispersed in the source rocks greatly influence the type of hydrocarbons generated during their thermal maturation (Tissot and Welte 1984; Peters and Cassa 1994). This kerogen facies can be evaluated using geochemical and petrological parameters (Tissot and Welte 1984; Hunt 1996). Here, the organic matter quality (or the type of kerogen) and its relevance with respect to the hydrocarbon generation potential were determined primarily from the bulk pyrolysis data, examining them from a geochemical point of view. These analyses indicated that the samples analyzed contained mainly types III and II/III kerogen (Fig 5). This was also suggested by the corresponding HI values, which were between 96 and $234 \mathrm{mg} \mathrm{HC} / \mathrm{g}$ TOC (Table 1). Considering these results, it can be inferred that the post-rift Abbas shale Formation in the Tihamah Basin can generate mainly gas and oil (Fig 7). Overall, our results indicate that the Abbas shale samples from the Kathib-01 well generally represent source rocks with an early level of thermal maturity with respect to the oil-generation window, and they should not yet have generated commercial amounts of petroleum. Despite being low in maturity, it is possible that these shales have not yet reached a sufficient level of burial maturity and that, hence, they cannot generate commercial petroleum. The source rock characteristics of the Abbas shale Formation in the deeper parts of the basin are promising for future oil and gas explorations, suggesting new targets.

\section{Conclusions}

A basic organic geochemical investigation was performed on 10 shale samples of the Pliocene Abbas Formation collected from an exploratory well (i.e., Kathib-01) in the Tihamah Basin. This study aimed to characterize the source rocks and their hydrocarbon generation potential. Our conclusions, which can be used to evaluate future prospects and exploration targets in the area, are as follows:

(1) The Abbas shale Formation has TOC contents ranging between $0.50 \%$ and $1.03 \%$, indicating that it is a fairgood source rock.

(2) The chemical Rock-Eval results revealed that the bulk kerogen in the Abbas shale Formation is mainly of type III and a mixture of type II/III kerogens. This shale can generate both oil and gas, with a high proportion of gas of a sufficiently mature level.

(3) The chemical maturity parameters (i.e., $T_{\max }$ and PI) indicated that the Abbas shale Formation is located at a shallow depth $(<1600 \mathrm{~m})$ and is currently in the early-mature stage with respect to the oil-generation window: Commercial oil should not have been generated yet. 
Fig. 5 Geochemical correlations between the HI, $T_{\max }$, TOC content, OI, and $S_{2}$ : The shale samples analyzed were dominated by type III and mixed type II/III kerogens
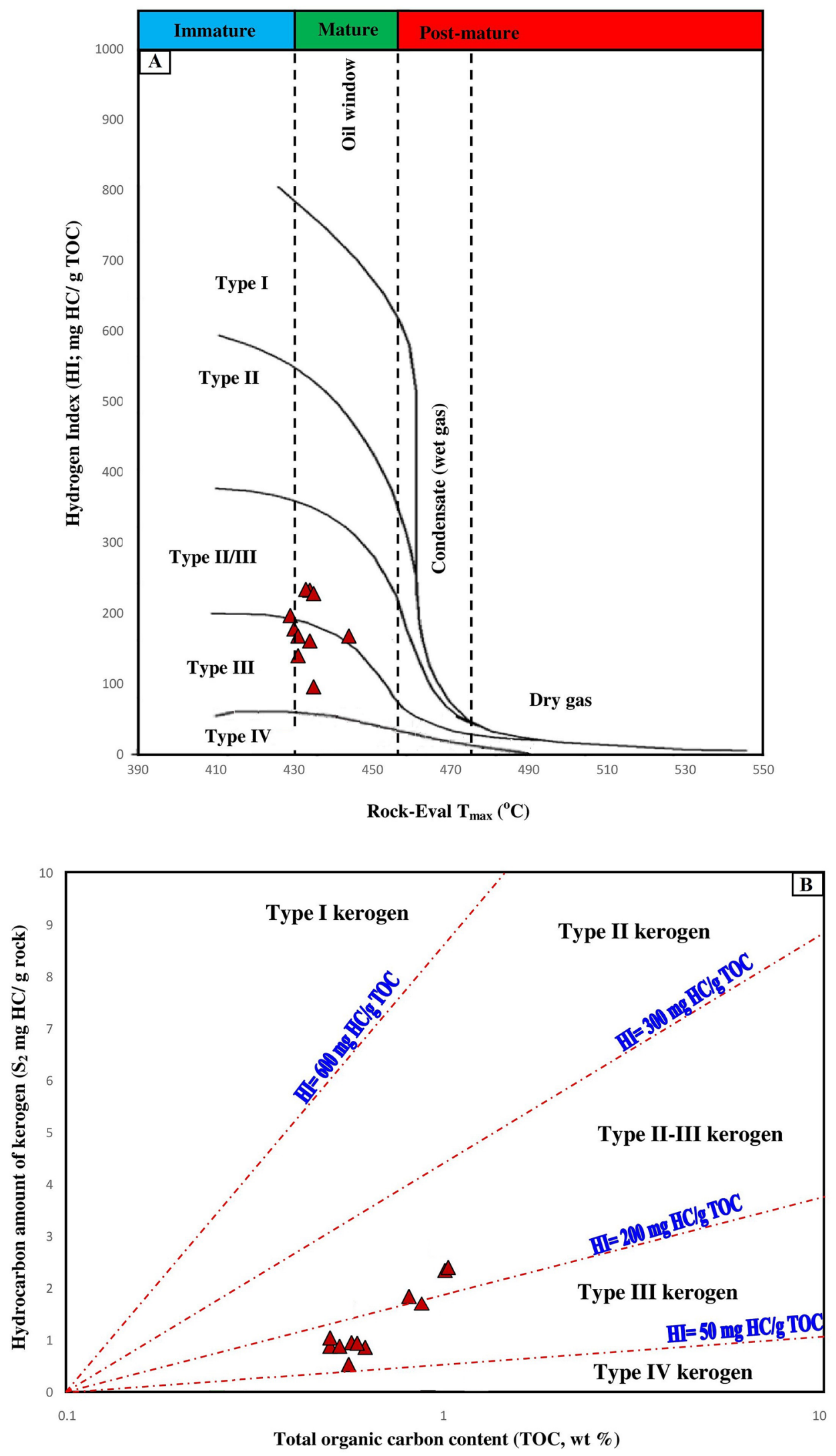


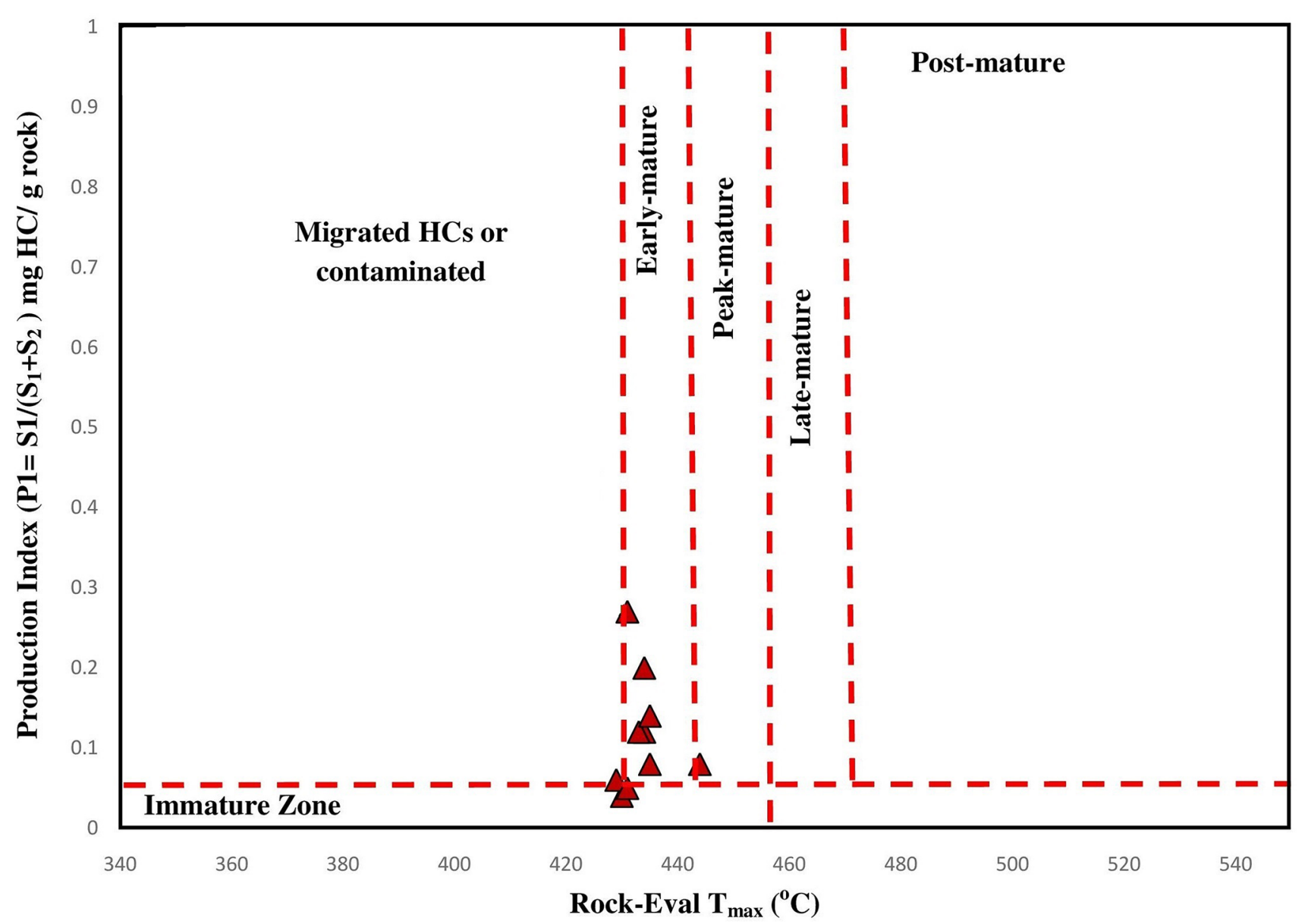

Fig. 6 Geochemical cross-plots of the pyrolysis parameter $T_{\max }$ vs. the PI, indicating the maturity level and nature of the hydrocarbon products in the shale samples analyzed 


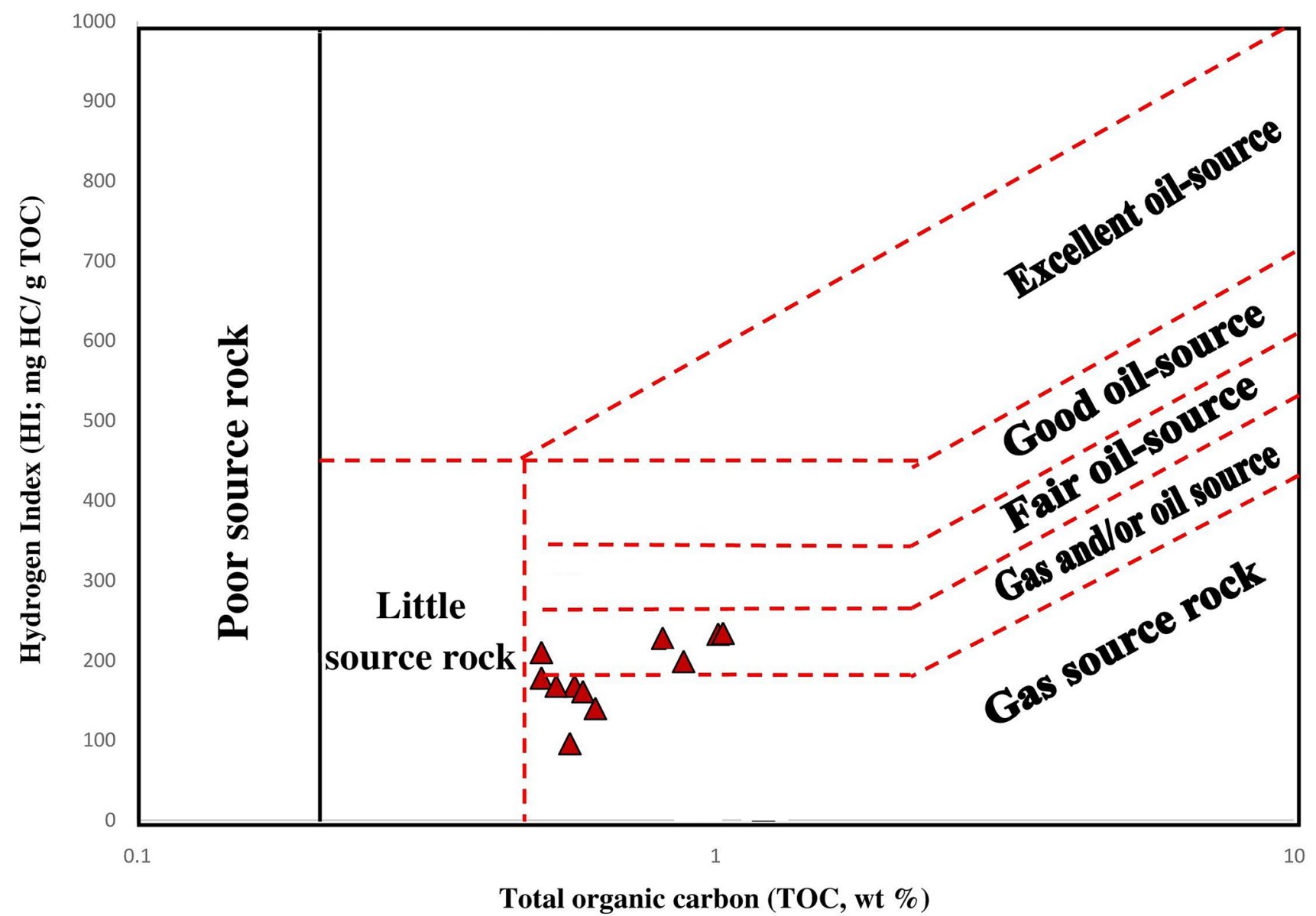

Fig. 7 Geochemical correlations between the TOC content and the Rock-Eval HI data: The shale intervals in the Abbas Formation represented good source rocks, generating mainly gas and low amounts of oil in the Tihamah Basin

Acknowledgments The senior author thanks Yemeni Ministry of Oil and Minerals and Petroleum Exploration and Production Authority (PEPA) for providing the data for this paper. The comments by anonymous reviewers that improved the revised manuscript are gratefully acknowledged.

\section{Funding No funding provide for this work.}

Open Access This article is licensed under a Creative Commons Attribution 4.0 International License, which permits use, sharing, adaptation, distribution and reproduction in any medium or format, as long as you give appropriate credit to the original author(s) and the source, provide a link to the Creative Commons licence, and indicate if changes were made. The images or other third party material in this article are included in the article's Creative Commons licence, unless indicated otherwise in a credit line to the material. If material is not included in the article's Creative Commons licence and your intended use is not permitted by statutory regulation or exceeds the permitted use, you will need to obtain permission directly from the copyright holder. To view a copy of this licence, visit http://creativecommons .org/licenses/by/4.0/.

\section{References}

Al-Kadasi MA (1994). Temporal and spatial evolution of the basal flow of the Yemen volcanic group Ph.D. Thesis, University of London (284 pp)

As-Saruri MA, Sorkhabi R, Baraba R (2010) Sedimentary basins of Yemen: their tectonic development and lithostratigraphic cover. Arab J Geosci 3:515-527

Bawazer W, Lashin A, Kinawy MM (2018) Characterization of a fractured basement reservoir using high-resolution 3D seismic and logging datasets: a case study of the Sab'atayn Basin. Yemen Plos One 13(10):e0206079

Beydoun ZR, Al-Saruri M, El-Nakhal H, Al-Ganad IN, Baraba RS, Nani ASO, Al-Aawah MH (1998). International Lexicon of Stratigraphy, 2nd edn. vol III, p 245 International Union of Geological Sciences and Ministry of Oil and Mineral Resources. Republic of Yemen, Publication 34

Dembicki HJ (2009) Three common source rock evaluation errors made by geologists during prospect or play appraisals. Am Assoc Pet Geol Bull 93(3):341-356

Espitalié J, Deroo G, Marquis F (1985) La pyrolyse Rock-Eval et ses applications and developments Oil Gas Sci. Technol Rev Inst Fr Pet Energ Nouv 40:563-580

Hakimi MH, Ahmed AF, Abdullah WH (2016) Organic geochemical and petrographic characteristics of the Miocene Salif organic-rich 
shales in the Tihama Basin, Red Sea of Yemen: implications for paleoenvironmental conditions and oil-generation potential. Int J Coal Geol 154:193-204

Hunt JM (1996) Petroleum geochemistry and geology, 2nd edn. WH Freeman and Company, New York

Langford FF, Blanc-Valleron MM (1990) Interpreting Rock-Eval pyrolysis data using graphs of pyrolizable hydrocarbons vs. total organic carbon. AAPG bulletin 74(6):799-804

Mattash MA (1994) Study of the cenozoic volcanics and their associated intrusive rocks in Yemen in relation to rift development, Ph.D Thesis, Hungarian academy of sciences, Eötvös Loránd University, Budapest (112 pp)

Mukhopadhyay PK, Wade JA, Kruge MA (1995) Organic facies and maturation of Jurassic/Cretaceous rocks, and possible oil-source rock correlation based on pyrolysis of asphaltenes, Scotian Basin, Canada. Org Geochem 22:85-104

Nasher MA (2010) Geology and geochemistry of the Tertiary volcanic rocks and their allied intrusion at NW Ad-Dhala province, Yemen, Ph.D Thesis, Cairo university, Egypt (250 pp)

Peters KE (1986) Guidelines for evaluating petroleum source rock using programmed pyrolysis. Am Asso Petrol Geol Bull 70:318-329
Peters K, Cassa M, (1994) Applied source rock geochemistry. In: Magoon LB, Dow WG (eds) The petroleum system from source to trap: AAPG Memoir 60, 93-117

Redfern P, Jones JA (1995) The interior rifts of Yemen-701 analysis of basin structure and stratigraphy in a regional plate tectonic context. Basin Res 7:337-356

Shah SBA, Ahmed A (2018) Hydrocarbon source rock potential of Paleocene and Jurassic deposits in the Panjpir oilfield subsurface, Punjab Platform Pakistan. Arabian J Geosci 11(20):607

SPT, 1194. The Petroleum Geology of the Sedimentary Basins of the Republic of Yemen, Unpublished report, vols 1-7

Tari G, Dellmour R, Rodgers E, Sultan S, Al Atabi A, Daud F, Salman A (2014) Seismic expression of salt tectonics in the Sab'atayn Basin, onshore Yemen. Interpretation 2:91-100

Tissot BP, Welte DH (1984) Petroleum formation and occurrence, 2nd edn. Springer Verlag, Berlin, p 699

Publisher's Note Springer Nature remains neutral with regard to jurisdictional claims in published maps and institutional affiliations. 